\title{
The scenario of researches regarding life experiences with cochlear implants: an integrative literature review
}

\author{
Marília Vieira Cavalcante ${ }^{1}$ \\ https://orcid.org/0000-0003-0516-9019 \\ Ivanise Gomes de Souza Bittencourt ${ }^{1}$ \\ https://orcid.org/0000-0002-9416-3964 \\ Ana Carolina Santana Vieira ${ }^{1}$ \\ https://orcid.org/0000-0002-7273-1414 \\ Jéssica do Nascimento Carneiro' \\ https://orcid.org/0000-0001-5538-4011 \\ Larissa de Morais Teixeira ${ }^{1}$ \\ https://orcid.org/0000-0002-6978-0805
}

Universidade Federal de Alagoas - UFAL, Maceió, Alagoas, Brasil.

Conflict of interests: Nonexistent

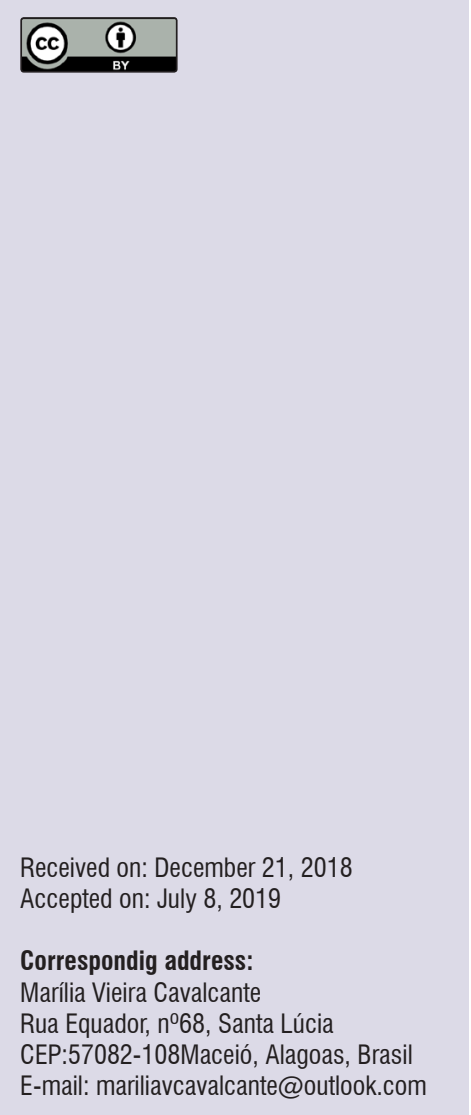

\section{ABSTRACT}

Purpose: to identify the scientific production regarding life experiences associated with the cochlear implant for the last ten years, including the process of education and presence of the family in this context.

Methods: this is an integrative review that researched articles published between 2008 and 2018, on the Brazilian portal: Coordination for the Improvement of Higher Education Personnel.

Results: after selecting and organizing the studies, the final sample consisted of ten articles; 2017 was the year with the greatest number of publications (three). In general, they addressed issues related to school performance, quality of life of cochlear implant users and their families, development of vocabulary and oral communication, and the meaning of cochlear implant for users and their families.

Conclusion: an increasing production of studies involving the cochlear implant, family and schooling was noticed, emphasizing the importance of new researches in this context to clarify further inquiries and their use as a tool to promote new strategies aiming to improve both the quality of life of cochlear implant users and the (re)habilitation process.

Keywords: Cochlear Implant; Family; Education 


\section{INTRODUCTION}

According to the Brazilian government's decree no. 5,296 , of December $2^{\text {nd }}, 2004$, disabling hearing loss is characterized by either partial or complete bilateral hearing loss, from forty-one decibels ( $\mathrm{dB}$ ) and above, assessed by audiogram at the frequencies of $500 \mathrm{~Hz}$, $1,000 \mathrm{~Hz}, 2,000 \mathrm{~Hz}$ and $3,000 \mathrm{~Hz}$; it may be manifested as mild, moderate, severe or profound. This definition has changed the text of the previous decree, which considered hearing loss the partial or complete loss of sound hearing possibilities beginning at 25 decibels (dB). This fact has been causing damage to the life of people with hearing loss, whose rights are often denied for not fitting in what the new decree declares'.

Hearing loss interferes in language and speech development, resulting in difficulties in learning, and in social, emotional, cognitive and academic development of the person with impairment ${ }^{2}$. The cochlear implant $(\mathrm{Cl})$ works transforming sound in electrical impulse, which is directly transmitted to the cochlear nerve. Hence, it benefits people with severe and profound sensorineural hearing loss, who take little or no advantage of conventional hearing aids ${ }^{3}$.

The $\mathrm{Cl}$ is an electronic prosthesis surgically implanted in the inner ear, made of two units: an external one, containing a microphone, a speech processor and a transmitting antenna; and an inner unit, surgically implanted, which contains a receiver/ stimulator and a thin electrode cable ${ }^{4}$. Undergoing such surgery demands a lot of reflection by candidates and their families, as it requires commitment of both, not only in the preoperative stage, but also in the follow-up, since after the $\mathrm{Cl}$ the oral and auditory (re)habilitation process involves speech-language pathologist and audiologist therapies, as well as the dedication of the user and all their relatives, especially when done in children.

Besides enabling people to access sounds and communicate orally, the $\mathrm{Cl}$ promotes the auditory (re) habilitation that minimizes or prevents restrictions caused by hearing loss, breaking barriers and paradigms in the communicative process. In addition to this, it's seen as an instrument aimed at facilitating social interaction, learning, and the person's cognitive and emotional development.

Thus, this review's objective is to identify the scientific production about life experiences associated with $\mathrm{Cl}$ in the last ten years, including the schooling process and family's participation in this context.

\section{METHODS}

Once the theme was established and the need for this review confirmed, the selection criteria were defined, the investigation started and the articles sought for. These were selected, their data analyzed and the results presented in the form of an integrative review. The integrative review of the literature was carried out through the portal of the Coordination for the Improvement of Higher Education Personnel (CAPES, its acronym in Portuguese) (http://www. periodicos.capes.gov.br/), a virtual library that collects and makes available to education and research institutions in Brazil the main national and international scientific productions.

The integrative review is a methodology capable of gathering and synthetizing knowledge related to a specific theme or issue and presenting the usefulness of the results in practical terms ${ }^{5,6}$.

The search was for articles published between 2008 and 2018, written in Portuguese, English or Spanish, and whose text was available in full; the emphasis was on the Brazilian texts. At first, the following combination of descriptors was used: "cochlear implant" and "life experience", through which 31 articles were identified; of these, only four were selected. Afterwards, the combination used was: "cochlear implant" and "family", and 28 articles were found; after excluding the repeated ones, three publications were selected. Lastly, the combination used was: "cochlear implant" and "school", with 19 articles found, of which three were selected. It had been established during the search at the CAPES portal that the descriptors had to be either in the title or in the subject of the publication, refining the search by means of the topics: cochlear implant, cochlear implants (these two both in English and Portuguese), psychology, children, hearing loss. Theses, dissertations and books were excluded, as well as other reviews and repeated articles. For the selection of these articles, all titles were read, followed by the reading of all the summaries, in order to verify whether they met the inclusion criteria.

The data of the ten selected article were organized in a spreadsheet containing: title, year, authors, objectives, participants, methodology and results, so the extraction of data from the articles would be facilitated. Then, the analysis of the gathered data was carried out. 


\section{LITERATURE REVIEW}

In this review, the articles selected in the database of the CAPES portal were published in 2017 (three), 2016 (one), 2015 (two), 2012 (two), 2010 (one), 2009 (one), most of them (five) having been published in a speechlanguage pathology and audiology periodical, followed by periodicals that dealt with psychology-related issues (three), one related to education, and one related to health promotion.

\begin{tabular}{|c|c|c|c|}
\hline & $\begin{array}{c}\text { Title } \\
\end{array}$ & Authors/Year & Periodical \\
\hline 1 & $\begin{array}{c}\text { Auditory and oral communication skills of } \\
\text { children and adolescents with hearing loss } \\
\text { and the speech-language and audiology } \\
\text { rehabilitation process }\end{array}$ & $\begin{array}{l}\text { Bicas, Guijo, Delgado- } \\
\quad \text { Pinheiro (2017) }\end{array}$ & $\begin{array}{c}\text { Rev. CEFAC - Speech, Language, } \\
\text { Hearing Sciences and Education } \\
\text { Journal }\end{array}$ \\
\hline 2 & Arithmetic for children with cochlear implant & Costa, Barbosa (2017) & $\begin{array}{c}\text { Journal of Research in Special } \\
\text { Educational Needs }\end{array}$ \\
\hline 3 & $\begin{array}{l}\text { Expressive vocabulary in children with } \\
\text { cochlear implant }\end{array}$ & $\begin{array}{l}\text { Colalto, Goffi-Gomez, } \\
\text { Magalhães, Samuel, Hoshino, } \\
\text { Porto et al (2017) }\end{array}$ & $\begin{array}{l}\text { Rev. CEFAC - Speech, Language, } \\
\text { Hearing Sciences and Education } \\
\text { Journal }\end{array}$ \\
\hline 4 & $\begin{array}{c}\text { Socioeconomic classification and quality of } \\
\text { life of relatives of children and adolescents } \\
\text { with hearing loss }\end{array}$ & $\begin{array}{l}\text { Nascimento, Schiling, } \\
\text { Biaggio, Kessler (2016) }\end{array}$ & $\begin{array}{l}\text { Rev. CEFAC - Speech, Language, } \\
\text { Hearing Sciences and Education } \\
\text { Journal }\end{array}$ \\
\hline 5 & $\begin{array}{l}\text { Effects of a program to teach reading on } \\
\text { the intelligibility of speech of children with } \\
\text { cochlear implant }\end{array}$ & $\begin{array}{l}\text { Lucchesi, Almeida-Verdu, } \\
\text { Buffa, Bevilacqua (2015) }\end{array}$ & $\begin{array}{c}\text { Psicologia reflexão e crítica } \\
\text { (Psychology, reflection and critique) }\end{array}$ \\
\hline 6 & $\begin{array}{l}\text { Oral language of adolescents with hearing } \\
\text { loss: speech-language pathologic and } \\
\text { audiological evaluation and teachers' reports }\end{array}$ & $\begin{array}{l}\text { Melo, Monteiro, Garcia } \\
\text { (2015) }\end{array}$ & $\begin{array}{l}\text { Rev. CEFAC - Speech, Language, } \\
\text { Hearing Sciences and Education } \\
\text { Journal }\end{array}$ \\
\hline 7 & $\begin{array}{l}\text { Assessment of school abilities in children } \\
\text { with cochlear implant }\end{array}$ & $\begin{array}{c}\text { Pinheiro, Yamada, } \\
\text { Bevilacqua, Crenitte (2012) }\end{array}$ & $\begin{array}{c}\text { Rev. CEFAC - Speech, Language, } \\
\text { Hearing Sciences and Education } \\
\text { Journal }\end{array}$ \\
\hline 8 & Health promotion of families of deaf children & $\begin{array}{l}\text { Frota, Amaral, Nobre, } \\
\text { Barbosa (2012) }\end{array}$ & $\begin{array}{l}\text { Rev. Brasileira de Promoção a Saúde } \\
\text { (Brazilian Journal of Health Promotion) }\end{array}$ \\
\hline 9 & $\begin{array}{l}\text { Cochlear implant in children: the parents' } \\
\text { point of view }\end{array}$ & $\begin{array}{l}\text { Yamanaka, Silva, Zanolli, } \\
\text { Silva (2010) }\end{array}$ & $\begin{array}{l}\text { Psicologia teoria e pesquisa } \\
\text { (Psychology, theory and research) }\end{array}$ \\
\hline 10 & $\begin{array}{l}\text { The experience of the adolescent with } \\
\text { cochlear implant }\end{array}$ & $\begin{array}{l}\text { Zanardi, Yamada, Bevilacqua } \\
\text { (2009) }\end{array}$ & $\begin{array}{l}\text { Psicologia em revista (Journal of } \\
\text { Psychology) }\end{array}$ \\
\hline
\end{tabular}

Source: developed by the author.

Figure 1. Articles about life experience, cochlear implant and schooling selected at the CAPES portal database

Regarding the objectives, the authors addressed issues concerning school performance, quality of life of the implant users and their families, development of vocabulary and oral communication, besides the importance of the $\mathrm{Cl}$ to the user and the family. The type of methodology used involved: semi-structured interview, recorded interview, the Brazilian Economic
Classification Criteria, the WHOQOL-BREF quality of life questionnaire, school performance test, the ABFW Child Language Test, and videos recorded during the application of a reading teaching and case study program. Without exceptions, the participants in the selected studies were children and adolescents users of $\mathrm{Cl}$, and their families. 


\begin{tabular}{|c|c|c|c|c|}
\hline Authors (year) & Objective & Participants & Methodology & $\begin{array}{c}\text { Conclusion } \\
\end{array}$ \\
\hline $\begin{array}{c}\text { Bicas, Guijo, } \\
\text { Delgado- } \\
\text { Pinheiro (2017) }\end{array}$ & $\begin{array}{l}\text { To analyze the auditory } \\
\text { and oral communicative } \\
\text { behavior in a group of } \\
\text { children and adolescents } \\
\text { with cochlear implant, } \\
\text { and to establish relations } \\
\text { with factors that interfere } \\
\text { in auditory rehabilitation. }\end{array}$ & $\begin{array}{l}13 \text { children or } \\
\text { adolescents with } \\
\text { bilateral profound } \\
\text { sensorineural } \\
\text { hearing loss. }\end{array}$ & $\begin{array}{c}\text { Scales and } \\
\text { questionnaires. }\end{array}$ & $\begin{array}{l}\text { There was a significant impact in communicati- } \\
\text { ve development, making evident that, the faster } \\
\text { the intervention, the better the results. It was } \\
\text { also evident that, the earlier the beginning of } \\
\text { usage of the cochlear implants, older the audi- } \\
\text { tory age and longer the period of rehabilitation, } \\
\text { the better the scores that assessed auditory } \\
\text { and verbal development. }\end{array}$ \\
\hline $\begin{array}{c}\text { Costa, Barbosa } \\
\text { (2017) }\end{array}$ & $\begin{array}{l}\text { To describe pedagogical } \\
\text { intervention carried out } \\
\text { for teaching and learning } \\
\text { arithmetic to a deaf child } \\
\text { with cochlear implant }\end{array}$ & $\begin{array}{l}\text { A child with } \mathrm{Cl} \text {, } \\
\text { enrolled in a } \\
\text { regular public } \\
\text { school. }\end{array}$ & Case study. & $\begin{array}{l}\text { The activities developed with the child provided } \\
\text { the quick and effective learning of the con- } \\
\text { cepts, which allows the conclusion that such } \\
\text { resources are effective and may be developed } \\
\text { in other contexts and realities. It is suggested } \\
\text { the carrying out of new researches and studies } \\
\text { that contribute, not only to the research in this } \\
\text { field, but also, and especially, to teaching and } \\
\text { learning of deaf children with Cl in school age. }\end{array}$ \\
\hline $\begin{array}{c}\text { Colalto, } \\
\text { Goffi-Gomez, } \\
\text { Magalhães, } \\
\text { Samuel, } \\
\text { Hoshino, Porto } \\
\text { et al. (2017) }\end{array}$ & $\begin{array}{l}\text { To verify the acquisition } \\
\text { of vocabulary in deaf } \\
\text { children with cochlear } \\
\text { implant, as well as the } \\
\text { factors that influence this } \\
\text { development. }\end{array}$ & $\begin{array}{l}20 \text { children with } \\
\text { Cl. }\end{array}$ & $\begin{array}{l}\text { The ABFW Child } \\
\text { Language Test. }\end{array}$ & $\begin{array}{l}\text { Children who have received the implant may } \\
\text { present performance similar to children with } \\
\text { normal hearing in the vocabulary test, depen- } \\
\text { ding on the variables that transcend age to the } \\
\text { implantation, or even the time of use of the co- } \\
\text { chlear implant. The family stimulation/ partici- } \\
\text { pation in the children's development has proven } \\
\text { to be of extreme importance in oral language } \\
\text { development. }\end{array}$ \\
\hline $\begin{array}{l}\text { Nascimento, } \\
\text { Schiling, } \\
\text { Biaggio, Kessler } \\
(2016)\end{array}$ & $\begin{array}{l}\text { To investigate the relation } \\
\text { of the socioeconomic } \\
\text { classification and the } \\
\text { perception of quality of } \\
\text { life of people who have } \\
\text { a relative with hearing } \\
\text { loss. }\end{array}$ & $\begin{array}{l}20 \text { relatives of } \\
\text { patients with } \\
\text { hearing loss. }\end{array}$ & $\begin{array}{l}\text { The Brazilian } \\
\text { Economic } \\
\text { Classification } \\
\text { Criteria and the } \\
\text { WHOQOL-BREF } \\
\text { quality of life } \\
\text { questionnaire. }\end{array}$ & $\begin{array}{l}\text { The study demonstrated that there was relation } \\
\text { between socioeconomic classification and the } \\
\text { perception of quality of life of the relatives, sin- } \\
\text { ce, the lower the socioeconomic classification, } \\
\text { the worse the perception of quality of life in all } \\
\text { the domains, except for the environmental do- } \\
\text { main. }\end{array}$ \\
\hline $\begin{array}{l}\text { Lucchesi, } \\
\text { Almeida- } \\
\text { Verdu, Buffa, } \\
\text { Bevilacqua } \\
\text { (2015) }\end{array}$ & $\begin{array}{l}\text { To assess the effects of } \\
\text { a program to teach the } \\
\text { reading of simple words } \\
\text { on the quality of speech. }\end{array}$ & $\begin{array}{l}\text { Two children with } \\
\text { sensorineural } \\
\text { hearing loss with } \\
\text { Cl. }\end{array}$ & $\begin{array}{l}\text { Assessment of the } \\
\text { children through } \\
\text { a software, with } \\
\text { sessions recorded } \\
\text { in video. }\end{array}$ & $\begin{array}{l}\text { Improvement on the quality of speech was ob- } \\
\text { served, when compared to the baseline, both } \\
\text { when words and pictures were used. Future } \\
\text { studies with a greater number of participants } \\
\text { and different outlining should verify benefits of } \\
\text { teaching programs to the rehabilitation process } \\
\text { of this population. }\end{array}$ \\
\hline $\begin{array}{c}\text { Melo, Monteiro, } \\
\text { Garcia (2015) }\end{array}$ & $\begin{array}{l}\text { To characterize the } \\
\text { language of adolescents } \\
\text { with hearing loss } \\
\text { who have learned to } \\
\text { communicate orally, } \\
\text { attending regular school, } \\
\text { as well as the perception } \\
\text { of the teacher regarding } \\
\text { the communication of } \\
\text { these students. }\end{array}$ & Nine adolescents. & $\begin{array}{l}\text { Recorded interview, } \\
\text { use of language } \\
\text { assessment } \\
\text { protocol. }\end{array}$ & $\begin{array}{l}\text { It was concluded that, in spite of the degree of } \\
\text { hearing loss of these people, a good perfor- } \\
\text { mance regarding communication was noticed, } \\
\text { being it effective in their daily life and in school. }\end{array}$ \\
\hline
\end{tabular}




\begin{tabular}{|c|c|c|c|c|}
\hline Authors (year) & Objective & Participants & Methodology & Conclusion \\
\hline $\begin{array}{l}\text { Pinheiro, } \\
\text { Yamada, } \\
\text { Bevilacqua, } \\
\text { Crenitte (2012) }\end{array}$ & $\begin{array}{l}\text { To evaluate and } \\
\text { characterize the school } \\
\text { development of children } \\
\text { with hearing loss with } \\
\text { cochlear implant, } \\
\text { between } 9 \text { and } 12 \text { years } \\
\text { old. }\end{array}$ & $\begin{array}{l}32 \text { children } \\
\text { from the first } \\
\text { to fifth grade } \\
\text { of Elementary } \\
\text { School. }\end{array}$ & $\begin{array}{l}\text { The School } \\
\text { Performance } \\
\text { Test (TDE, as } \\
\text { abbreviated in } \\
\text { Portuguese) } \\
\text { and the Rapid } \\
\text { Automatized } \\
\text { Naming Test (RAN). }\end{array}$ & $\begin{array}{l}\text { It was concluded that } 74 \% \text { of the children had } \\
\text { an inferior school performance in the evalua- } \\
\text { tions, and that there was no relation between } \\
\text { these results and the rapid naming, since this } \\
\text { is within average and it's a requirement for rea- } \\
\text { ding, and those participating in this study pre- } \\
\text { sented satisfactory reading skill. }\end{array}$ \\
\hline $\begin{array}{l}\text { Frota, Amaral, } \\
\text { Nobre, Barbosa } \\
\quad(2012)\end{array}$ & $\begin{array}{l}\text { To investigate the } \\
\text { impact of hearing loss } \\
\text { on the deaf child's } \\
\text { family life, identifying } \\
\text { the family's knowledge } \\
\text { regarding deafness and } \\
\text { understanding how the } \\
\text { parents cope with their } \\
\text { deaf child's diagnosis } \\
\text { and treatment. }\end{array}$ & $\begin{array}{l}\text { Six mothers of } \\
\text { children with } \\
\text { hearing loss. }\end{array}$ & $\begin{array}{l}\text { Semi-structured } \\
\text { interview. }\end{array}$ & $\begin{array}{l}\text { Promoting changes is necessary, with } \\
\text { emphasis on the participation of relatives as } \\
\text { caregivers and facilitators of the deaf child's } \\
\text { development. In Speech-Language Pathology } \\
\text { and Audiology, this attitude means finding } \\
\text { new ways of identifying the necessary for } \\
\text { the person. It requires strategies that value } \\
\text { their opinion, enabling them to express their } \\
\text { expectations, perceptions, representations and } \\
\text { feelings. }\end{array}$ \\
\hline $\begin{array}{l}\text { Yamanaka, } \\
\text { Silva, Zanolli, } \\
\text { Silva (2010) }\end{array}$ & $\begin{array}{l}\text { To analyze the parents' } \\
\text { point of view regarding } \\
\text { cochlear implant. }\end{array}$ & $\begin{array}{l}10 \text { parents } \\
\text { of children } \\
\text { candidates for } \\
\text { Cl at the Clinics } \\
\text { Hospital of } \\
\text { The University } \\
\text { of Campinas } \\
\text { (UNICAMP). }\end{array}$ & Recorded interview. & $\begin{array}{l}\text { It was concluded that, in the process of learning } \\
\text { about the implant, the parents were anxious } \\
\text { and anguished when presented to the risks } \\
\text { and benefits of the procedure, and their need } \\
\text { to choose for performing or not the cochlear } \\
\text { implant, in addition to being seen as a solution } \\
\text { for their children's deafness and as a possibility } \\
\text { for them to have a better future. }\end{array}$ \\
\hline $\begin{array}{l}\text { Zanardi, } \\
\text { Yamada, } \\
\text { Bevilacqua } \\
(2009)\end{array}$ & $\begin{array}{l}\text { To understand the life of } \\
\text { an adolescent with } \mathrm{Cl} \\
\text { in a phenomenological } \\
\text { perspective }\end{array}$ & $\begin{array}{l}\text { Four female } \\
\text { adolescents, } \\
\text { between } 13 \text { and } \\
16 \text { years old. }\end{array}$ & Recorded interview. & $\begin{array}{l}\text { It was concluded that the school context was } \\
\text { characterized by difficulties, especially in Por- } \\
\text { tuguese class; the family context was experien- } \\
\text { ced as a place of support; dating and flirting } \\
\text { were filled with feelings of inferiority and preju- } \\
\text { dice. the importance of friendship was evident } \\
\text { for the adolescents, and the cochlear implant } \\
\text { meant satisfaction for hearing and evidence of } \\
\text { hearing loss. }\end{array}$ \\
\hline
\end{tabular}

Source: developed by the author.

Figure 2. Objectives, participants, methodology and conclusion of the articles included in the review

Four thematic units were established for the presentation of the results, correlating the contents regarding life experiences and $\mathrm{Cl}$, namely: relation with the $\mathrm{Cl}$, family, schooling, and development of the child with $\mathrm{Cl}$.

\section{Theme 1: Relation with the Cl}

A study with ten parents of children candidates for a $\mathrm{Cl}$ observed that, for them, $\mathrm{Cl}$ represented an instrument to improve their children's quality of life. They believed that daily life situations, as studying, working, socializing and communicating would be made easier, in addition to the most important, the possibility of the child developing as any other person. The $\mathrm{Cl}$ came to be seen as the solution to hearing loss, besides bringing hope of improving the child's quality of life ${ }^{7}$.

The parents saw in the $\mathrm{Cl}$ the possibility of the child hearing, as well as the expectation of acquiring oral language, so that they would become independent and autonomous, prepared to face society and the future, being at ease that, even when they were absent, their children would have a peaceful life ${ }^{7}$. 
Situations common to people who hear become especially significant for $\mathrm{Cl}$ users, such as: the possibility of talking on the phone, hearing their friends' voices, following school activities, listening and understanding. These were highlighted as things to be proud of in their lives. With it comes the possibility of participating in the world of sounds, broadening knowledge and communication with other people, improving quality of life and well-being, promoting an increase in self-confidence ${ }^{8}$.

Being excluded and rejected are also part of the life of $\mathrm{Cl}$ users. The stigma associated with hearing loss oftentimes makes them feel inferior to others, and the $\mathrm{Cl}$ represents a confirmation of their impairment and the needs related to it, which sometimes bring them shame. On the other hand, the pleasure and the need of feeling included in the world of sounds were mentioned as being more important than those ${ }^{8}$.

\section{Theme 2: Family}

The family is the institution that spends more time with the child, the one that knows their needs and is their source of total confidence, as it fulfills its role of protecting and bringing up. It transmits respect, certainty and assurance of support, being thus fundamental for the children with $\mathrm{Cl}^{9}$.

Regarding progress in interaction and communication of children with $\mathrm{Cl}$, the family, and particularly the mother, who lives intensely with the child, must develop strategies using everyday situations in order to create appropriate environments to stimulate hearing and language. For this to happen effectively, the family must be very well informed about the process involved in rehabilitating the child with $\mathrm{Cl}$, as well as aware of the needs related to this process ${ }^{9}$.

When evaluating the development of oral language in children with $\mathrm{Cl}$, it was perceived that time of use of the $\mathrm{Cl}$ was not in itself enough for the development of vocabulary, and that the involvement of the family interfered in the consistency of use of the device, which reflected directly on the use and acquisition of vocabulary. In this study, children who better developed and better profited from the equipment were those whose families participated more actively on a daily basis in the process of rehabilitation ${ }^{10}$.

The family context is seen by the $\mathrm{Cl}$ users as a place of support in times of school questions, in developing verbal language, where they can discuss their needs, especially in the issues related to hearing loss ${ }^{8}$.
For some parents, overwhelmed with doubts and the impact caused by the diagnosis, the $\mathrm{Cl}$ was also seen as a tool that would make their child overcome hearing loss, as they clung to it as a comforting possibility. Most of the information was acquired from the professionals in specialized services; however, they had previously sought to learn about it in various sources (magazines, videos, internet), looking for possibilities. Hence, it's noticeable the need for the professional team to be capable of clearly and coherently transmitting the necessary information?.

In face of so many uncertainties regarding their child's hearing loss, the families many times weren't capable of establishing an analytical reasoning of the situation, which most of the times was caused by the lack of information about hearing loss, the necessary interventions, the $\mathrm{Cl}$ and the whole context the child was in. This hindered them from taking a stand and taking actions that would transform the situation?

The parents' decision was actually influenced by the type of counseling they received, the quality of the information that had been transmitted and the support given by the health services, thus directly influencing their decision-making. When welcomed by the professionals and humanely oriented, the parents felt confident in choosing for practices that would help them and favor their child's development. For parents that want their child to use the $\mathrm{Cl}$ and so develop oral communication, information is an essential factor ${ }^{7}$.

When referring to relatives of people with any deficiency, it's important to highlight their quality of life, as caring for someone with deficiency demands dedication, which sometimes makes caregivers give up or reduce their paid workday, especially in cases involving children and adolescents with greater need of attention and dedication. The quality of life of people with hearing loss and their relatives is affected by many factors that involve the hearing loss itself, as well as necessary changes in daily living in order to provide for the well-being and development of their children ${ }^{11}$.

The analysis of the quality of life of relatives of people with hearing loss revealed that the most affected areas were related to leisure, financial situation, caring for their own health and physical safety, and opportunities of acquiring new information/abilities, which was explained by the attention being fully directed to the child's needs. The authors observed also that most of the interviewed families had financial difficulties, for, in most cases, it was necessary for them to leave a paid employment in order to care for the child ${ }^{11}$. 
The $\mathrm{Cl}$ in children brings difficulties both in adapting the external unit and in facing an unfamiliar situation that may cause the family to be anguished and fearful regarding the child's future and needs. The parents build expectations and hope with the results of the $\mathrm{Cl}$; they change their routine and the family context, so that the child's well-being and development be a priority?

\section{Theme 3: Schooling}

The speech of $\mathrm{Cl}$ users is characterized by omissions, distortions and switching of phonemes. As the development of children with $\mathrm{Cl}$ was observed while they were learning to read and write, it was possible to conclude, by the results, that the participants had a low performance in reading, being on the level with children the same age without hearing loss ${ }^{12}$.

In children who underwent the surgery precociously, around 2 years of age, a good development in reading was observed. And, when the reading comprehension of children using $\mathrm{Cl}$ was compared to that of children wearing PSAP, it was observed that those using $\mathrm{Cl}$ had a significantly better comprehension, making evident the quality of the sound provided by the $\mathrm{Cl}$ and its effectiveness in the rehabilitation process ${ }^{13}$.

In a study carried out with nine teenagers using $\mathrm{Cl}$, the school context was characterized by difficulties, especially regarding the Portuguese Class. The teenagers complained that their understanding of the teacher's speech was sometimes impaired, due to the speed with which the teacher spoke and to their limited vocabulary resulting from the hearing loss, hindering their general comprehension of the subject. Asking for the teacher to frequently repeat the same content became a source of shame, and the difficulties in understanding grew worse. This situation evidenced the need of a professional to help interpreting the language, which is a common difficulty to many people with congenital hearing loss. The teacher must be aware of their children's needs in order to offer quality teaching according to each one's individuality ${ }^{8}$.

When interviewed, teachers of students with $\mathrm{Cl}$ reported that these students made themselves understood when they spoke, showing to have comprehension, answered coherently when asked, and participated in the classes They had difficulty understanding when many people were speaking during conversations, however they performed well in dialogues with only one person. Besides these circumstances, they had difficulty in writing and in reporting experiences they had gone through ${ }^{14}$.
In the school environment, the $\mathrm{Cl}$ became an aid, facilitating the relationship with classmates and teachers and giving them more independence; thus, it contributed to the possibility of their users attending regular classrooms and having good academic and social performance. Bullying, practiced by their own classmates, was emphasized by $\mathrm{Cl}$ users and their mothers; among other reasons, it was motivated by the hearing loss itself and by the need of having the content of conversations constantly repeated, due to their not understanding. This situation brought discomfort and sadness, showing that society is not ready to welcome someone with hearing loss 8 ,9.

The use of drama in educating people with hearing loss proved to be a helpful tool for text comprehension and interpretation, as well as a possibility of solving the students' difficulties in understanding writing. As the pedagogical intervention using drama and visual resources was performed with a child with $\mathrm{Cl}$, it was possible to confirm the efficacy of the mentioned resources, once the child had developed and improved skills related to comprehending written texts and solving math problems, which stimulated the notion of space, creativity and logical reasoning ${ }^{13,14}$.

It's not enough to include the child with $\mathrm{Cl}$ in the regular school system; a thorough pedagogical project must be carried out, having in view the child's potentials, in the perspective of an inclusive education that considers the needs and the reality of the child, so that learning may be effectively provided ${ }^{14}$.

\section{Theme 4: development of the child with $\mathrm{Cl}$.}

The child with hearing loss many times has difficulty in their development; the necessity of communicating and expressing their desires and needs often cause their behavior to be affected. Hearing loss becomes a social obstacle due to the child's isolation, with the risk of them being hindered in their cognitive development and their behavior, including aggressiveness. As the child receives the $\mathrm{Cl}$, oral language becomes a possibility, and the child starts feeling that they belong to the communicative process in the family context; they begin to be heard and feel the need to be understood'

Early $\mathrm{Cl}$ procedure and follow-up with the rehabilitation program, including speech-language and audiology therapy, with the family's involvement, makes the child with hearing loss to have a development closer to that of a child with normal hearing. The comparison of development of a child with $\mathrm{Cl}$ who underwent all the abovementioned criteria, with a child with normal 
hearing whose age was similar to the time of sound stimulation, revealed approximated performances. A child who was submitted to $\mathrm{Cl}$ procedure before the 12 months of age had performance and development reaching the maximum expected for a child with normal hearing at the same age ${ }^{15}$.

When working with rehabilitating children with $\mathrm{Cl}$, oral, auditory and cognitive development should be thought of. The child needs to hear the message, understand it and have the ability of reproducing it; thus, they develop their skills and critical thinking. The children who have received the implant present vocabulary of varied results, but they may achieve the expected results both for their auditory and chronological age, as long as they receive early stimulation and their family's participation ${ }^{10}$.

For the children with $\mathrm{Cl}$ to present a better cognitive performance and oral language development, it's important that they undergo speech-language and audiology therapy and that they be included in the school environment. These factors quicken learning and promote a better performance in their development ${ }^{16}$.

\section{CONCLUSION}

The context of studies related to $\mathrm{Cl}$, family and schooling has grown in number in the last years. The importance of an early $\mathrm{Cl}$ procedure to the development of the child, bringing about benefits to the other stages of life, in addition to its importance as a facilitating instrument in acquiring oral language and school learning, has been observed. Familial participation and integration have shown to be fundamental for the care to be effective. The carrying out of new studies involving relatives of $\mathrm{Cl}$ users and their schooling process is noticeably an important strategy in the present situation; it is a tool for promoting strategies aimed to improve the quality of life of those fitted with the implants, and develop and implement facilitating and groundbreaking strategies for the process of schooling and improvement of (re)habilitation.

\section{REFERENCES}

1. Brasil. Decreto o 5.296 , de 2 de dezembro de 2004. Regulamenta as Leis nos 10.048 , de 8 de novembro de 2000, que dá prioridade de atendimento às pessoas que especifica, e 10.098, de 19 de dezembro de 2000, que estabelece normas gerais e critérios básicos para a promoção da acessibilidade das pessoas portadoras de deficiência ou com mobilidade reduzida, e dá outras providências. [Internet]. Diário Oficial [da] República Federativa do Brasil. 2004 dez. 2 [acesso em 2019abr. 3]. Disponível em: http://www. planalto. gov.br/ccivil_03/_Ato2004-2006/2004/Decreto/ D5296.htm

2. Ministério da Saúde (Brasil), Secretaria de Atenção à Saúde, Departamento de Ações Programáticas Estratégicas. Manual de legislação em saúde da pessoa com deficiência. Brasília; 2006.

3. Narsala HR, Goffi V, Guedes MC, Peralta CGO. Implante coclear na adolescência: quatro candidatos, quatro percursos ao implante coclear. Intl. Arch. Otorhinolaryngol. 2008;12(1):126-32.

4. Costa FFSD. Implantes cocleares: diferentes abordagens cirúrgicas e possíveis complicações [Dissertação]. Lisboa (PT): Universidade de Lisboa, Faculdade de Medicina de Lisboa; 2017.

5. Mendes KS, Silveira RCCP, Galvao CM. Revisão integrativa: método de pesquisa para a incorporação de evidências na saúde e na enfermagem. Texto contexto - enferm. 2008;17(4):758-64.

6. Souza MT, Silva MD, Carvalho R. Revisão integrativa: o que é e como fazer. Einstein. 2010;8(1 Pt 1):102-6.

7. Yamanaka DAR, Silva RBP, Zanolli ML, Silva ABP. Implante coclear em crianças: a visão dos pais. Psicologia teoria e pesquisa. 2010;26(3):465-73.

8. Zanardi MMB, Yamada MO, Bevilacqua MC. A experiência do adolescente usuário de implante coclear. Psicologia em revista. 2009;15(1):69-89.

9. Frota MA, Amaral LCG, Nobre CS, Barbosa PME. Promoção da saúde de famílias de crianças surdas. Rev. Bras Promc Saúde. 2010;25(2):70-5.

10. Colalto CA, Goffi-Gomez MVS, Magalhães ATM, Samuel PA, Hoshino ACH, Porto BL et al. Expressive vocabulary in children with cochlear implants. Rev. CEFAC. 2017;19(3):308-19.

11. Nascimento GB, Schiling NO, Ubal SR, Biaggio ELV, Kessler TM. Socio-economic classification and quality of life of family members of children and teenagers with hearing disability. Rev. CEFAC. 2016;18(3):657-66.

12. Lucchesi FDM, Almeida-Verdu ACM, Buffa MJMB, Bevilacqua MC. Efeitos de um programa de ensino de leitura sobre a inteligibilidade da fala de crianças usuárias de implante coclear. Psicologia reflexão e crítica. 2015;28(3):500-10. 
13. Pinheiro ABSM, Yamada MO, Bevilacqua MC, Crenitte PAP. Avaliação das habilidades escolares de crianças com implante coclear. Rev. CEFAC. 2012;14(5):826-35.

14. Costa MPR, Barbosa RS. Aritmética para criança com implante coclear. J Res Spec Educ Needs. 2017;16(1):159-63.

15. Bicas RS, Guijo LM, Delgado-Pinheiro EMC. Oral communication and auditory skills of hearing impaired children and adolescents and the speech therapy rehabilitation process. Rev. CEFAC. 2017;19(4):465-74.

16. Melo EB, Monteiro TR, Garcia VL. Oral language of hearing impaired adolescents: phonoaudiological evaluation and teachers report. Rev. CEFAC. 2015;17(4):1288-300. 